\title{
DYNAMIC SIMULATION TOOL FOR PLANNING AND OPTIMISATION OF SUPPLY PROCESS
}

\author{
Grznar, P.; Gregor, M.; Gaso, M.; Gabajova, G.; Schickerle, M. \& Burganova, N. \\ Department of Industrial Engineering, Faculty of Mechanical Engineering, University of Zilina, \\ Slovakia \\ E-Mail: patrik.grznar@fstroj.uniza.sk,milan.gregor@fstroj.uniza.sk,martin.gaso@fstroj.uniza.sk, \\ gabriela.gabajova@fstroj.uniza.sk, kpi@fstroj.uniza.sk,natalia.burganova@fstroj.uniza.sk
}

\begin{abstract}
The article deals with the use of dynamic simulation tools for planning and optimising changes in the supply process carried out by an automated guided vehicle (AGV). The integration of new products and the overall increase of the production capacity of the assembly line in the automotive company are foreseen to overexpose some transport node. For problem-solving in practice was applied statisticalexperimental research method. The article in its core deals with the designing and creating of a simulation model of AGV-transport processes using dynamic simulation, which is designed to check the patency of routes, the feasibility of processes and detect bottlenecks. Three proposals to reduce logistics downtime were verified. Based on the results of the simulation, one was selected to be applied. After applying the solution, the production line tact increased by $35 \%$. Based on the results of the experiments conducted on the current situation simulation model, it is important to propose improvements to the AGV's management and transportation systems. The output is a design with virtual verification of a new supply process without bottlenecks.

(Received in December 2020, accepted in May 2021. This paper was with the authors 2 months for 2 revisions.)
\end{abstract}

Key Words: Modelling and Simulation, Optimisation of the Supply Process, Automated Guided Vehicle, Automotive Industry

\section{INTRODUCTION}

The main purpose of the business is to meet the customer's needs. Offering the customer what he expects and needs is a prerequisite for successful sales of the product itself. This ensures revenues that meet the needs of their own, the needs of the business entity [1]. Nevertheless, how to succeed in the competitive environment of the $21^{\text {st }}$ century? How to persuade a customer to choose our product? The customer is primarily interested in functionality, price and quality. We can influence price and quality by thoroughly preparing the production process and its service processes to achieve maximum quality and quantitative effect with minimal resources $[2,3]$. By rigorously preparing processes, we set the attributes of production and service processes and their needs, which will accompany production throughout the product life cycle. A prerequisite for a thriving organisation is continuous improvement - a constant circle of optimisations in the life cycle of the product [4].

Furthermore, it is the good preparation of processes in the planning phase that eliminates the high cost of later process rebuilding and optimisation [5]. Simulation is one of the most widely used operations-research and management science techniques, if not the most widely used [6]. The simulation is possible to classify in statistical experimental methods because it works on the same theoretical basis, like the methods of mathematical statistics [7]. The importance of simulation grows mainly with the increasing complexity of systems no other method allows systems "future looking" with the same accuracy and denunciation capability as simulation $[8,9]$. The use of simulation is possible in particular where it is necessary to ascertain the outcome of the activity, and a normal human estimate is no longer sufficient for this, therefore the simulation has been developed mainly as a supporting technology of a digital factory [10]. 
When designing and implementing a new manufacturing system, introducing or implementing changes, several questions arise as to how to select the appropriate type of production facility, how to incorporate it into the production disposition, how to deal with tool logistics and chip management, how to select the appropriate type of transport and handling system (type, number, runways, speed) or for job shop scheduling [11-13]. Simulation as an optimisation tool is increasing on importance and can be used as a tool to validate proposed solutions without interference with the real system and errors is eliminating in the preparation phase $[14,15]$. The obtained possibility is here to authentify planned changes and find the appropriate model or aid right before its actual realisation. The value of simulation lies in exploring the system's behaviour under a range of operational domains which may be expensive or even infeasible to do with the real-world system [16-18].

However, also there is valid saying garbage in - garbage out in other words inaccurate inputs also result in inaccurate outputs, so it is necessary to properly ensure all stages of the creation of the simulation model, especially data collection and analysis [19]. Another area involved in a correct model is the reduction of the problem and abstraction of some elements [20]. Understanding the relationships between the different variants and the gradual creation of new ones can be obtained by optimal or suboptimal solution [21].

The article's core deals with the design of the supply process carried out through AGV in the automotive, industrial plant and shows how to use computer simulation to analyse current and proposed changes. This was done due to preparing supply processes for the production of the newly implemented product portfolio with lower tact time. The aim of simulation runs is to verify the patency and continuity of processes with minimising costs. Based on the simulation model outputs, a suitable variant was proposed for the application and economic evaluation and return of investments $(R O I)$. Both scientific and professional benefits consist of applying simulation to support management decision-making to save process innovation costs. A research statistical-experimental method was applied to the solution and was created 11 types of entities and more than 160 objects with defined parameters representing the entire production logistics system of a plant. Some sensitive data worked within the model are not included in the article these are in particular the tact's high, production volume and the cost of implementing the resulting solution. The simulation is carried out in Siemens AG Tecnomatix Plant Simulation software.

\section{MATERIAL AND METHODS}

\subsection{Defining of solving process inputs}

The article deals with a simulation that can verify whether there are bottlenecks in the system and, based on outputs, propose the most appropriate solution to minimise the necessary investments while ensuring a safe transition to higher capacities without compromising production or forced multi-cost, due to operational interventions because of system impassability. The subject of optimisation is the supply system in an automotive company. For supply are used AGVs, see Figs. 1 and 2. The AGVs use routes that are shown graphically in Fig. 3.

The company plans to increase tact time by $35 \%$ for its production lines. Organisation changes are needed to accelerated tact times. The simulation aims to optimise supply routes for weighing parts from Supermarket 1, Supermarket 2, Circuit 1 and Circuit 4. In Fig. 3 are outlined routes for the above-mentioned circuits. Circuit 1 and Circuit 4, outlined by a yellow colour, has 2 Pcs AGVs on Circuit 1 and only 1 Pcs of AGV on Circuit 4. Circuit 2 in Fig. 3 coloured by red has 4 Pcs. of AGVs. Route of the Supermarket 2 called Circuit 3 outlined by blue colour has 7 Pcs of AGVs on circuits. Route Circuit 5 has green colour and have 6 Pcs. of AGVs on the circuit. 


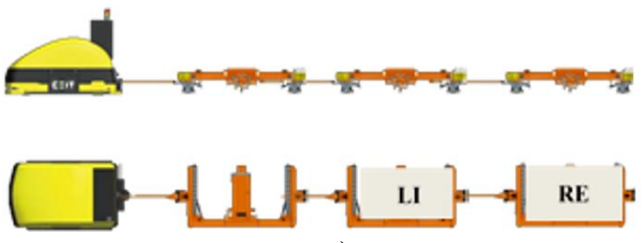

a)

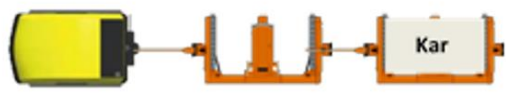

b)

Figure 1: a) AGV "Circuit 4" pulling 3 trucks (2 full-Left side + Right side and 1 for exchange); b) AGV "Circuit 1" pulling two trucks (1 loaded, 2 for exchange).

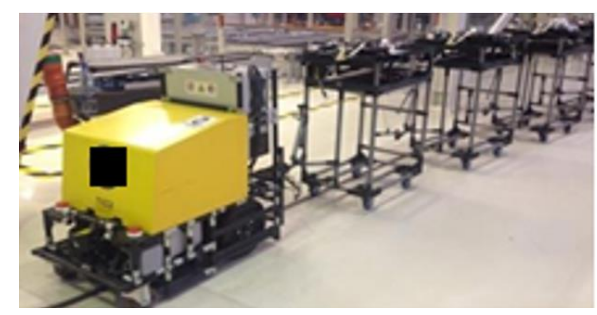

a)

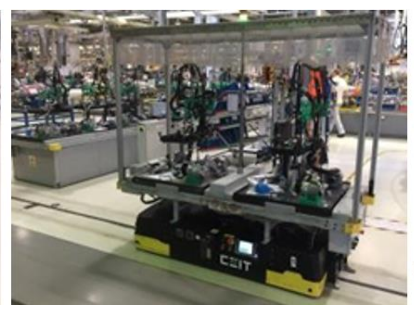

b)

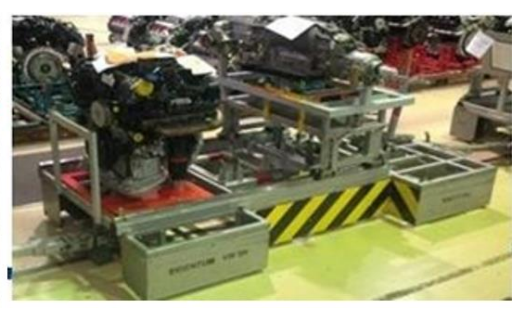

c)

Figure 2: a) AGV "Circuit 2" pulling three trucks; b) AGV "Circuit 3" with 2 Pcs. of a sequent buffer; c) AGV "Circuit 5" with 2 Pcs. of trucks.

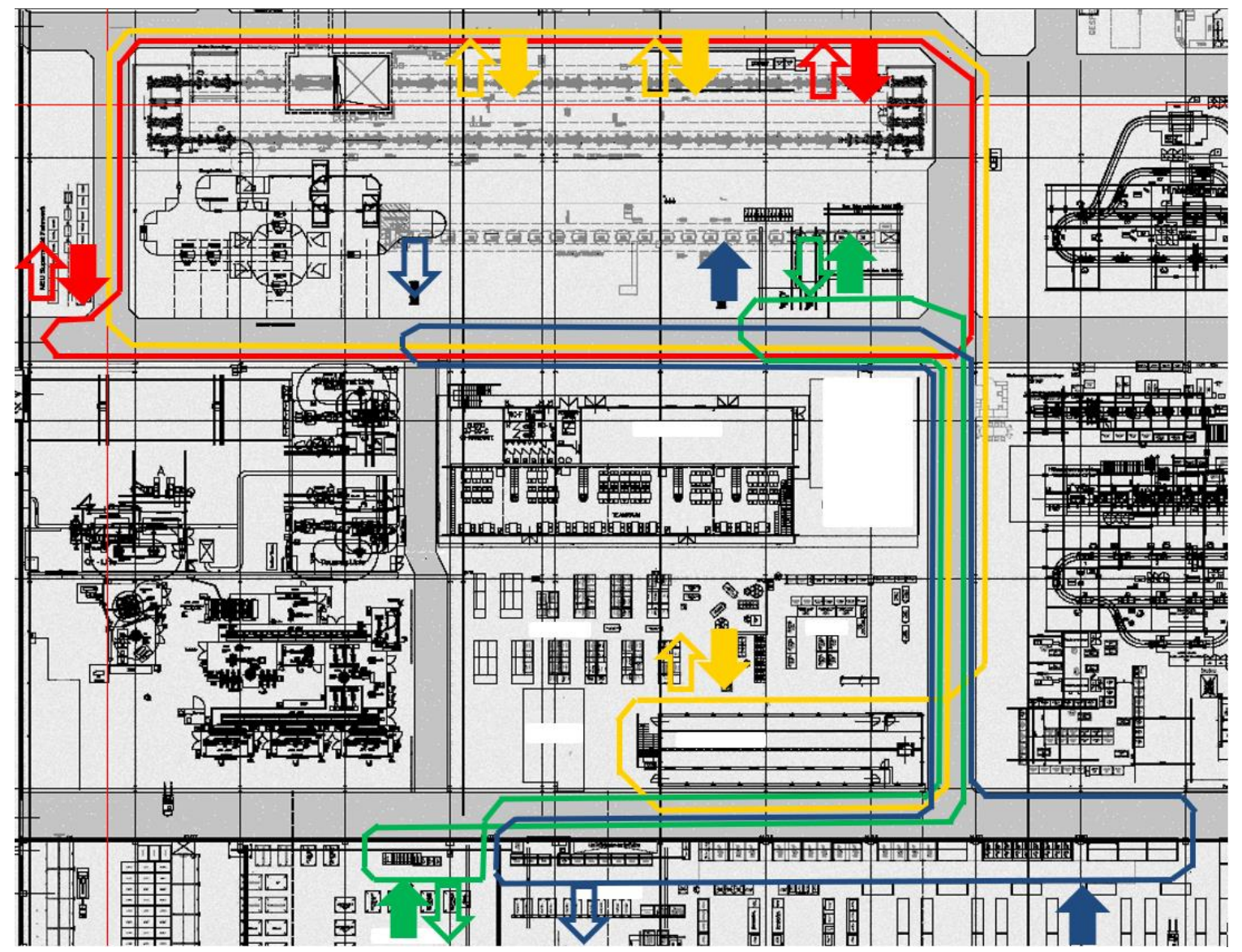

Figure 3: Supply routes to be checked by dynamic simulation.

Explanatory notes and information to Fig. 3:

- empty arrow - empty palette direction / sequential truck;

- full arrow - full palette direction / sequential truck.

For model parameterisation, input data is required. Among these data within our model is data from the manufacturer of AGV devices. The AGV system deployed in this section of the 
hall comes from CEIT Technical Innovation, s.r.o. Žilina. For modelling, the technical parameters of the deployed technique were used:

- turn radius of the sets - depends on the size of the pulling trucks (see Fig. 4);

- for AGV radius, the values selected are truck length $1600 \mathrm{~mm}$, truck width $1200 \mathrm{~mm}$ and radius $2000 \mathrm{~mm}$ required;

- speed of AGV devices - depends on where AGV is currently located.

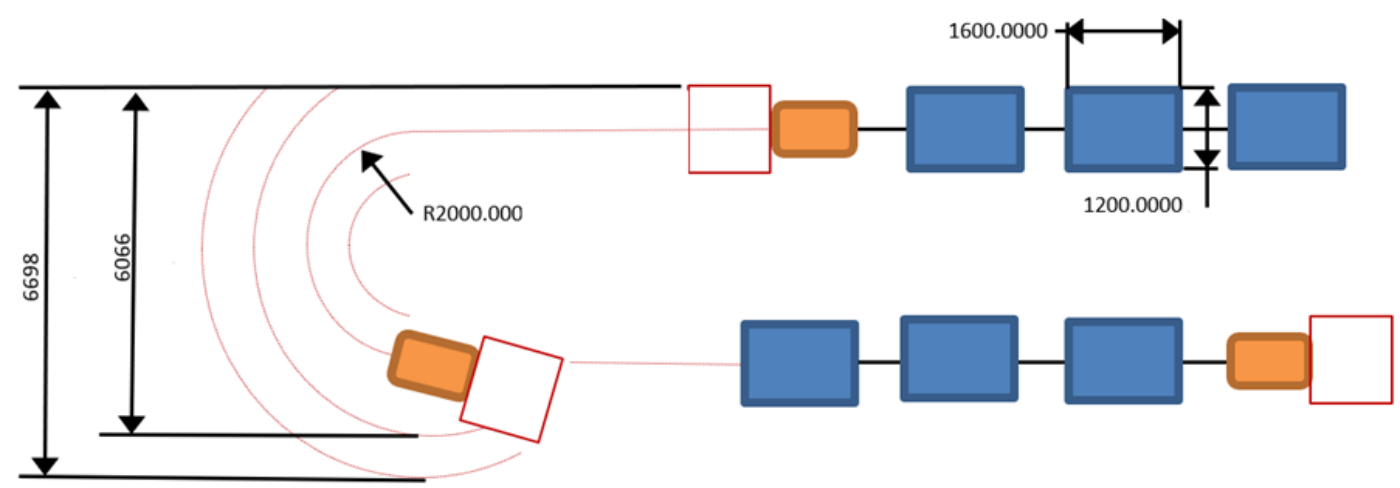

Figure 4: Sketch of AGV turning.

Although the company indicates a maximum speed of $2 \mathrm{~m} / \mathrm{s}$ and $1 \mathrm{~m} / \mathrm{s}$ for the Circuit 2 AGV for the types mentioned above of equipment, it is clear that such speed is not achieved due to the number of turns, movement of persons and possible disruptive influences (runway blocking). Therefore, on average, a speed of $0.8 \mathrm{~m} / \mathrm{s}$ is usually entered into the simulation for direct direction, $0.3 \mathrm{~m} / \mathrm{s}$ for turn passage and acceleration and/or deceleration of $0.25 \mathrm{~m} / \mathrm{s}$.

In this solution, we will not consider pulling trucks' weight, which impacts the choice of the appropriate technique, because we are making a change already on the existing process, and any possible changes will be an extension or modification of existing facilities.

Data on individual supply routes necessary for the calculation of the minimum number of tractors and trucks on the circuit show Table I and Table II.

Table I: Overview of technology and inventory.

\begin{tabular}{|c|c|c|c|c|c|c|c|c|c|}
\hline \multirow{2}{*}{$\begin{array}{l}\text { AGV } \\
\text { circuit }\end{array}$} & \multirow{2}{*}{$\begin{array}{l}\text { Length } \\
\text { of } \\
\text { circuit } \\
(\mathrm{m})\end{array}$} & \multirow{2}{*}{$\begin{array}{c}\text { Curve } \\
\text { (No.) }\end{array}$} & \multirow{2}{*}{$\begin{array}{c}\text { No. of } \\
\text { AGVs/ } \\
\text { circuit } \\
\text { (No.) }\end{array}$} & \multicolumn{3}{|c|}{ No. of tracks for AGV } & \multirow{2}{*}{$\begin{array}{c}\text { Supply / } \\
\text { AGV } \\
\text { (No. of } \\
\text { products) }\end{array}$} & \multirow{2}{*}{$\begin{array}{c}\text { Time } \\
\text { for load } \\
\text { AGV } \\
\text { set (s) }\end{array}$} & \multirow{2}{*}{$\begin{array}{l}\text { Time for } \\
\text { unloading } \\
\text { AGV set } \\
\text { (s) }\end{array}$} \\
\hline & & & & Full & $\begin{array}{l}\text { Empty for } \\
\text { exchange }\end{array}$ & Sum & & & \\
\hline Circuit 1 & 442 & 11 & 2 & 1 & 1 & 2 & 9 & 53 & 83 \\
\hline Circuit 2 & 242 & 9 & 4 & 3 & 0 & 3 & 3 & 151 & 336 \\
\hline Circuit 3 & 365 & 10 & 7 & 2 & 0 & 2 & 2 & 221 & 221 \\
\hline Circuit 4 & 494 & 10 & 1 & 2 & 1 & 3 & 24 & 575 & 575 \\
\hline Circuit 5 & 319 & 10 & 6 & 2 & 0 & 2 & 2 & 112 & 112 \\
\hline
\end{tabular}

Table II: Route lengths and limits.

\begin{tabular}{|c|c|c|c|c|c|c|}
\hline Parameter & $\begin{array}{c}\text { Length of } \\
\text { circuit (m) }\end{array}$ & $\begin{array}{c}\text { Curve } \\
\text { (No.) }\end{array}$ & $\begin{array}{c}\text { Route (full } \\
\text { speed) (m) }\end{array}$ & $\begin{array}{c}\text { Route (limit } \\
\text { speed) (m) }\end{array}$ & $\begin{array}{c}\text { Route mean } \\
\text { speed (m) }\end{array}$ & $\begin{array}{c}\text { Route speed } \\
\text { limitation } \\
(\mathrm{m})\end{array}$ \\
\hline Circuit 1 & 442 & 11 & 398 & 44 & 387 & 55 \\
\hline Circuit 2 & 242 & 9 & 206 & 36 & 197 & 45 \\
\hline Circuit 3 & 365 & 10 & 325 & 40 & 315 & 50 \\
\hline Circuit 4 & 409 & 10 & 369 & 40 & 444 & 50 \\
\hline Circuit 5 & 319 & 10 & 279 & 40 & 269 & 50 \\
\hline
\end{tabular}




\section{RESULTS}

\subsection{Creation, validation and verification of the simulation model}

Based on input data, a simulation model was created, verified and validated. Verification means checking the model's internal logic, examining whether all necessary details are displayed for the proper running of simulated processes. In addition, all syntax and logical errors are removed from the model. Validation means checking the conformity of the simulation model with the real process. The model confirmed the real situation, where tractors and sets' supply of processes is sufficient, and there is also no blocking and shutdown of production. After carrying out the simulation after analysis of the simulation experiment, it follows that the line is supplied on all nodes without risk of production failure due to non-delivery of the material on time. Based on the inspection and comparison with the real process, we can conclude that the simulation model is relevant to the simulated real situation and we can move on to experiments with the new capacity structure of the production line.

\subsection{Development of experiments for new production parameters}

The sub-chapter deals with the analysis of process changes and their impact on the numbers of tractors and sets. At the same time, the sub-chapter described the content of changes in simulation models that define individual variants as well as the course of experiments.

Analysis of process changes and their impact on tractor and assembly numbers: Previous input data show that the tact time is in actual process higher than that which is changed to lower values by rebuilding and modifying the production line. As a result of this change, a higher frequency of supply becomes necessary. The effect on the supply routes in the selected section and the number of tractors and sets in them can now be checked. To calculate the approximate number of $\mathrm{AGV}$ tractors needed (in the form of static calculations) together with the number of trucks, Eq. (1), the number of circulations, Eq. (2), the sum of possible circulations, Eq. (3), availability time AGV, Eq. (4), the time need to one circulation of route, Eq. (5), we will use the following relationships, which are modified in MS Excel format:

$$
\begin{gathered}
\text { Number of trucks }=\operatorname{Roundup}\left(\frac{\sum \text { needed circulation (for shift) }}{\sum \text { potencial circulation (for shift) }} ; 0\right) \\
=\operatorname{Roundup}\left(\frac{\sum \text { vehicle in manufacturing program (for shift) }}{\text { supply on one circulation } \Sigma} ; 0\right)
\end{gathered}
$$

Explanation: The number of products in this case $=$ products/shift. Supply for one circulation differs from the individual supply routes, and it is necessary to refer to that cell in the formula in the table.

$$
\begin{gathered}
\Sigma \text { Possible circulation }=\text { Rounddown }\left(\frac{\text { Availability time AGV (for shift) }}{\text { Time need for one circulation of route }} ; 0\right) \\
\text { Availability time AGV }= \\
=\text { Availability time on change }- \text { time to recharge }- \text { random influences }
\end{gathered}
$$

Explanation: The available time for the shift is 7.5 hours, i.e. $450 \mathrm{~min}$ or $27.000 \mathrm{~s}$, the charging time is roughly $20 \%$ of this time, and the random influences depend on the circumstances and environment. In our case, we count $10 \%$ of the available time for the shift.

Time need for one circulation of route $=$

$$
\begin{aligned}
& =\left(\frac{\Sigma \text { Length straight section }}{\emptyset \text { speed on straight section }}\right)+\left(\frac{\Sigma \text { Length of curve }}{\emptyset \text { speed in curve }}\right)+\Sigma \text { Time on load } \\
& +\Sigma \text { Time on unload }
\end{aligned}
$$


Explanation: The lengths of the straight sections were measured from the layout or physically in the hall. The length of the turns in relation to the passage of the whole set, in this case, is calculated $5 \mathrm{~m}$. Speeds for the straight section are calculated $0.8 \mathrm{~m} / \mathrm{s}$ and for turn $0.3 \mathrm{~m} / \mathrm{s}$. Loading and landing times, in this case, were measured in a real environment. These relationships have been deployed to MS Excel, see Table III.

Table III: Calculation table - for check the necessary numbers of tractors - static calculation.

\begin{tabular}{|c|c|c|c|c|c|c|c|}
\hline $\begin{array}{c}\text { AGV } \\
\text { circuit }\end{array}$ & $\begin{array}{c}\text { Length of } \\
\text { circuit (m) }\end{array}$ & $\begin{array}{c}\text { Curve } \\
\text { (No.) }\end{array}$ & $\begin{array}{c}\text { Time need } \\
\text { for circuit } \\
\text { (s) }\end{array}$ & $\begin{array}{c}\text { One infill = } \\
\text { supply (No. } \\
\text { of products) }\end{array}$ & $\begin{array}{c}\text { AGV } \\
\text { need } \\
\text { (No.) }\end{array}$ & $\begin{array}{c}\text { Actual } \\
\text { using AGV } \\
\text { (No.) }\end{array}$ & $\begin{array}{c}\text { Actual } \\
\text { AGV need } \\
\text { (No.) }\end{array}$ \\
\hline Circuit 1 & 442 & 11 & 803 & 9 & 2 & 2 & 0 \\
\hline Circuit 2 & 242 & 9 & 904 & 3 & 4 & 4 & 0 \\
\hline Circuit 3 & 365 & 10 & 1,002 & 2 & 7 & 7 & 0 \\
\hline Circuit 4 & 494 & 10 & 1,872 & 24 & 1 & 1 & 0 \\
\hline Circuit 5 & 319 & 10 & 727 & 1 & 10 & 6 & 4 \\
\hline
\end{tabular}

It is clear from the calculations in Table III that a reserve available to us is sufficient to cover a given increase for 4 out of 5 circuits, but for the Circuit 5 , an increase of 4 pieces of AGV equipment is required. The reason is apparent in the change in the concept of weighing, which was forced by the increase in variants. One AGV pulls two sets in the current state, while in the new enforced concept, it is one set. It is positive for the planned condition that there is no increase in tractors on the circuits except one. For these four circuits, this means that we will achieve even better efficiency and load capacity of the equipment by increasing production capacity. It is then necessary to examine in the simulation model what will mean an increase of the Circuit 5 by 4 Pcs. of tractors.

Variant "A", modification of the simulation model and effect of the experiment: The positive thing is that the technique is increased to only 1 circuit. The first proposal is " $\mathrm{A}$ " to leave routes and circuits unchanged and to add the missing technique to the Circuit 5 . The model is modified by adding four sets to the mentioned route and then running a simulation run, evaluating the simulation results.

The main route of all five circuits is blocked, according to simulation experiments carried out on the modified model. The reason is as predicted in the undersized route of the Circuit 5, which the other four pieces of sets are no longer able to implement capacity. The simulation shows that the Circuit 5, which has a single waiting position for three sets, does not fit capacity to ensure the smooth delivery of the material after the automated technique has been increased (see Fig. 5).

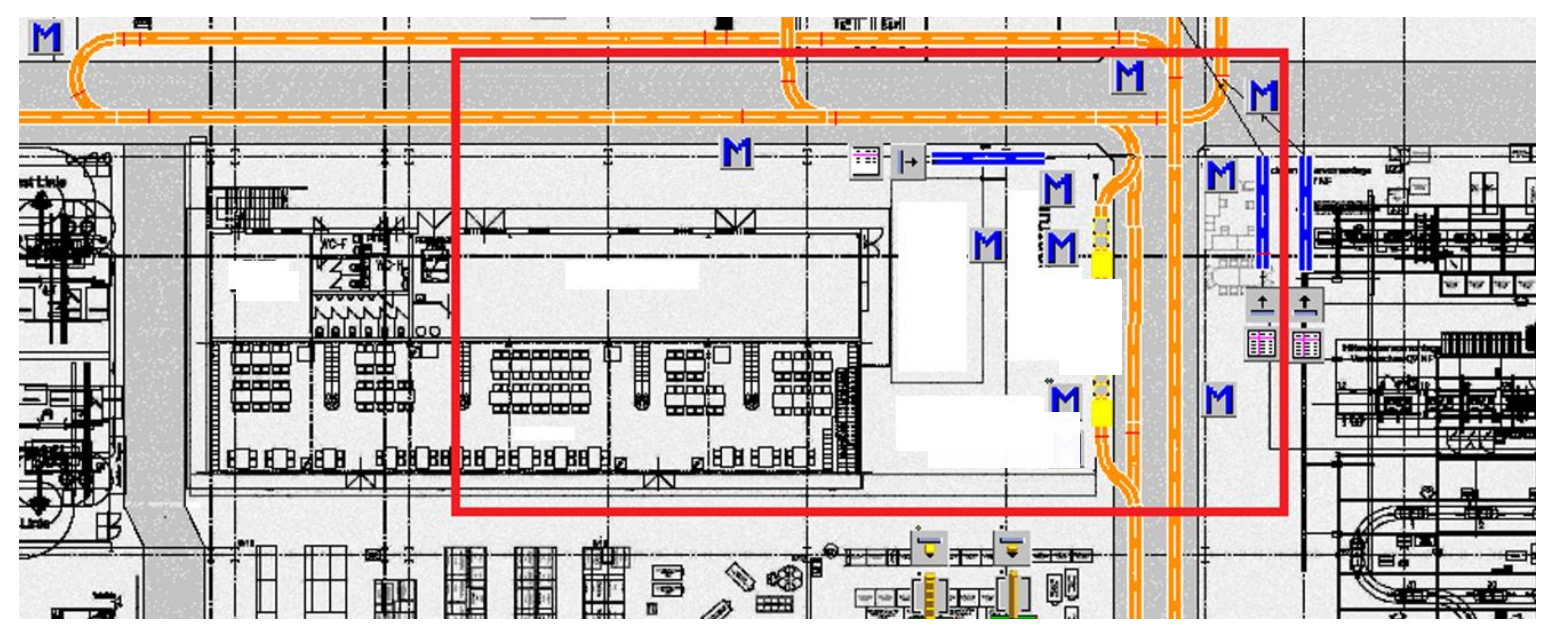

Figure 5: The blocking area in the "A" variant experiment. 
Blocking routes and influencing production supply best demonstrates chart of activity and waiting devices in Fig. 6, which shows that the risk of a blackout occurs at all supply node, most on the Circuit 3.

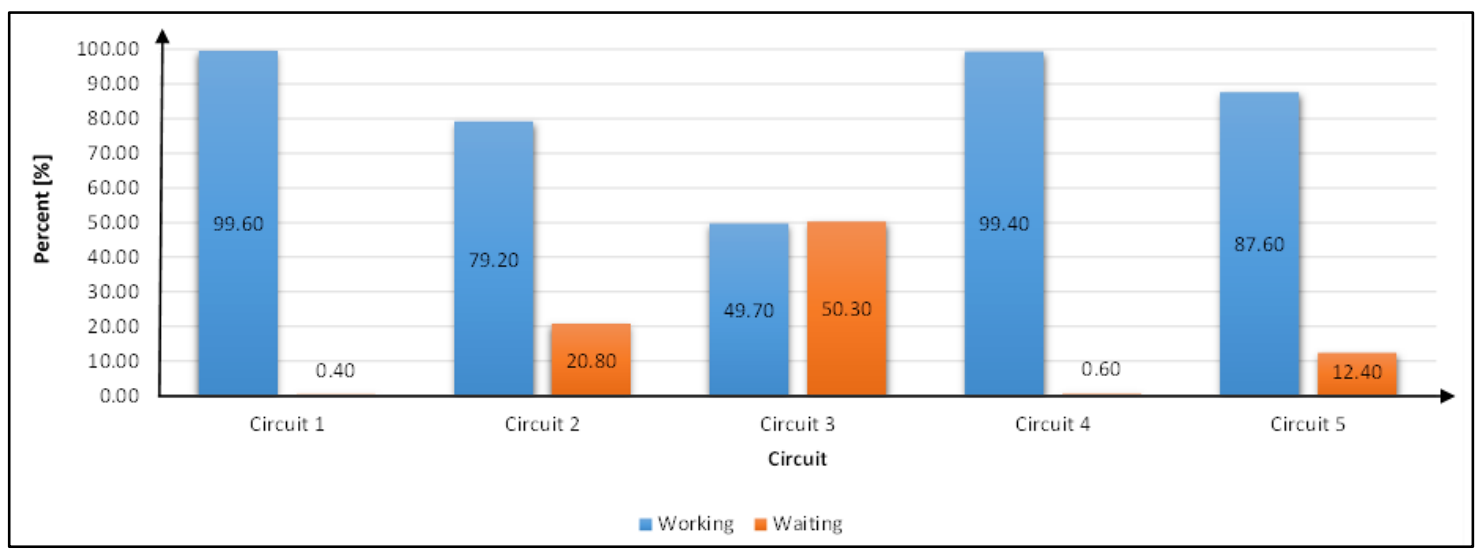

Figure 6: Impact of supply on the activity of production facilities - Variant "A".

Variant "B", modification of the simulation model and effect of the experiment: Based on the results of the version "A" tests, the initial issue was caused by the aggregation of Circuit 5 sets in waiting positions. A second idea was generated after these sets blocked the most burdensome node in this portion of the hall. Proposal "B" is to lengthen the waiting position or add another waiting position to allow for further sets to be accumulated (see Fig. 7).

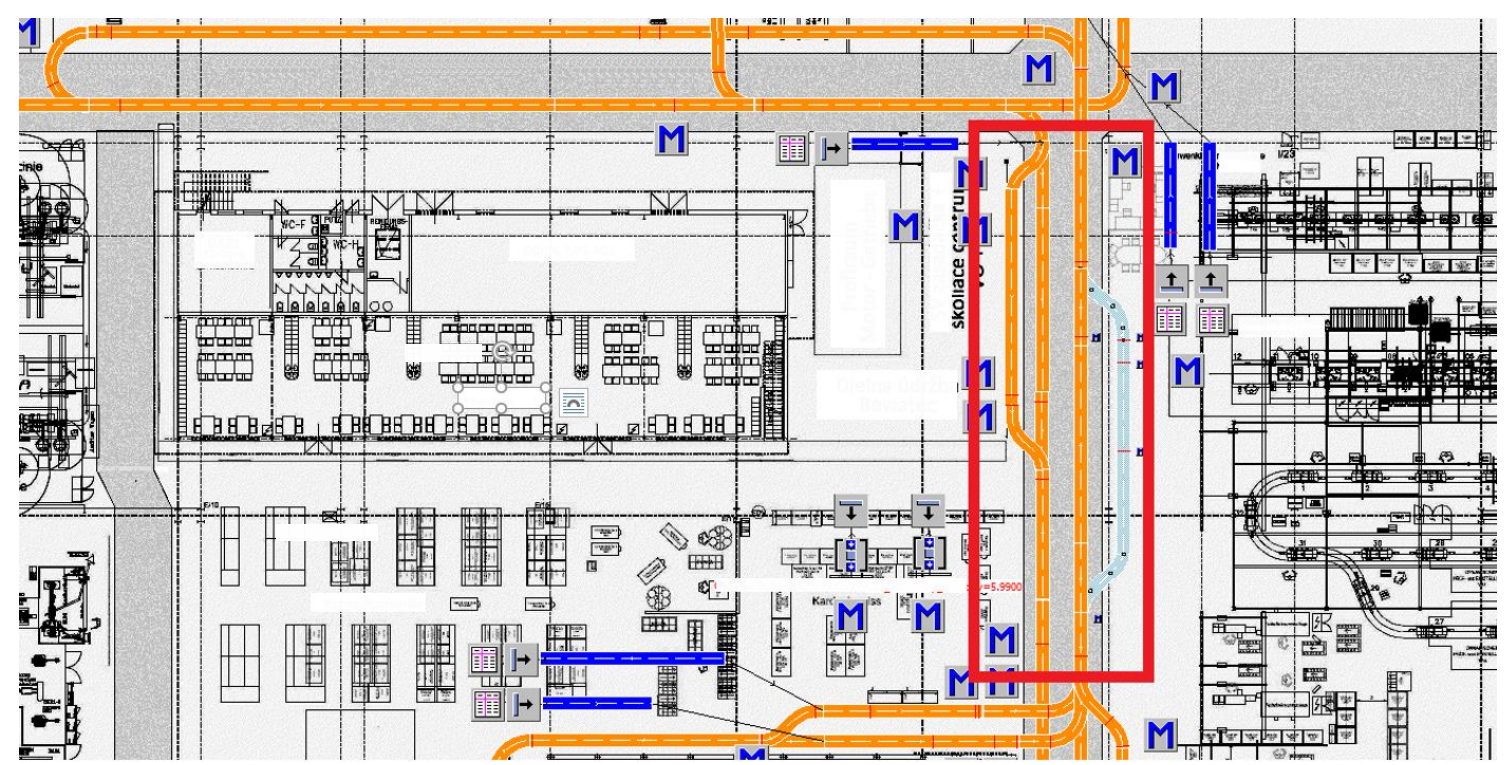

Figure 7: Variant "B" - integration of additional waiting positions.

However, based on the hall's current layout, the distribution of other processes in this section is no longer possible. Change is only possible in the case of expensive chain changes for other sections. From a time point of view and due to the economic demands of a possible redevelopment and the risks associated with the continuity of parallel processes, this proposal was rejected.

Variant " $C$ ", modification of the simulation model and effect of the experiment: The only solution to ensure the patency of supply routes is to create additional waiting points for the Circuit 5 and also to relieve the connecting section between the assembly and sequential workplaces. A possible solution was provided by modifying the maintenance workshop, which was located at the welding line for exhaust systems and formed a natural obstacle to other 
possibilities in the tracing of material flows. The modification consisted of extending the welding line and centralising the maintenance of the equipment in this hall. This opened the section between the built-in (office and team rooms) and the exhaust weldment room. Variant " $\mathrm{C}$ " takes advantage of this change of hall layout and allows to implement of the extension of "Trucks" from the current three stands to a total of 6 stands and the unifying of the route Circuit 5. The difference between the original route and the proposed route is shown (see Fig. 8). After measuring the route, the route was shortened from the current $319 \mathrm{~m}$ to $294 \mathrm{~m}$, which creates a positive effect for further potential capacity increase (see Fig. 9).

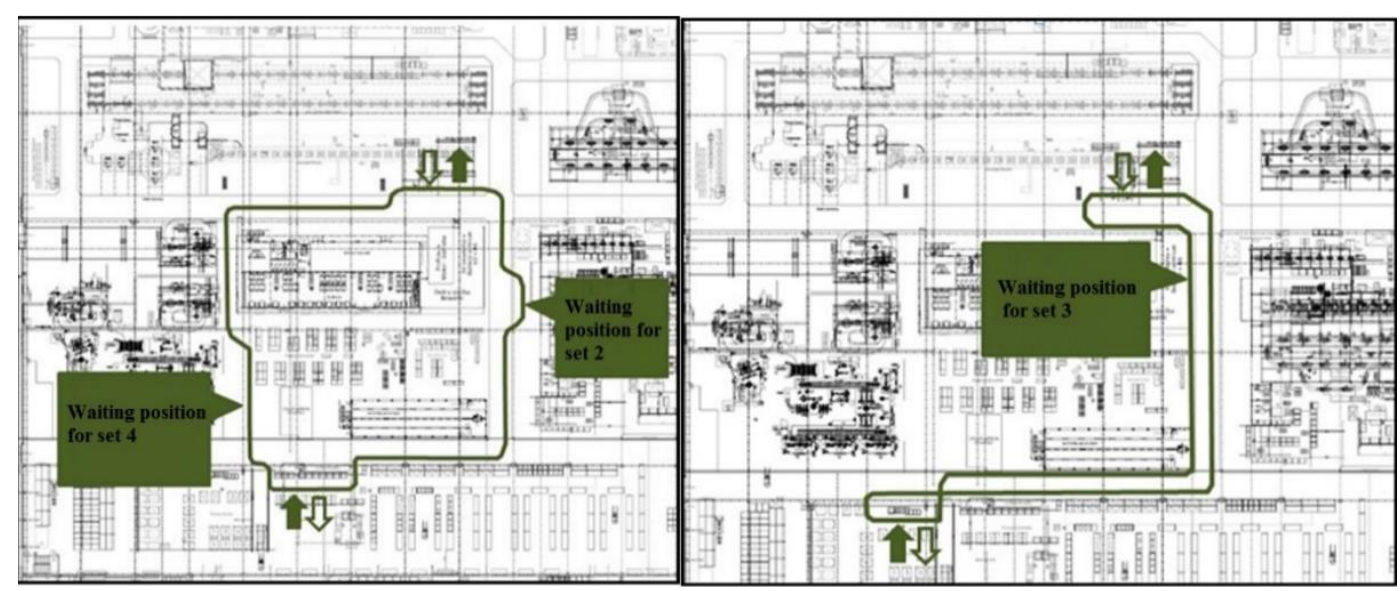

a)

b)

Figure 8: Routes for Circuit 5: a) the new route; b) the old route.

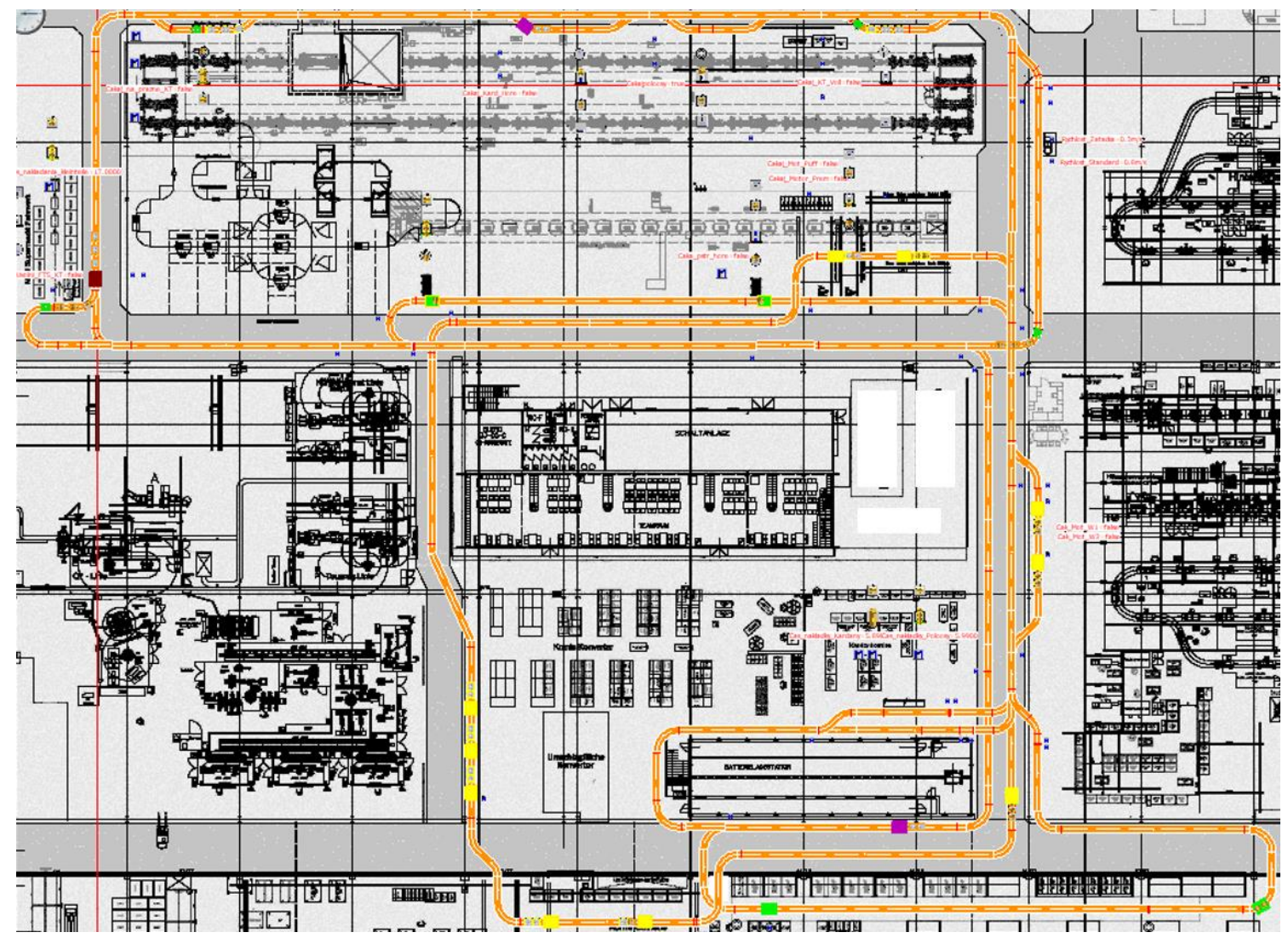

Figure 9: A modified simulation model for variant "C".

After experiments in the modified model, it was found that the design was in order, and the simulation runs were conducted without blocking the devices. The experiments' output 
represents Fig. 10, which confirms the running of production facilities without blackouts and waiting due to missing material.

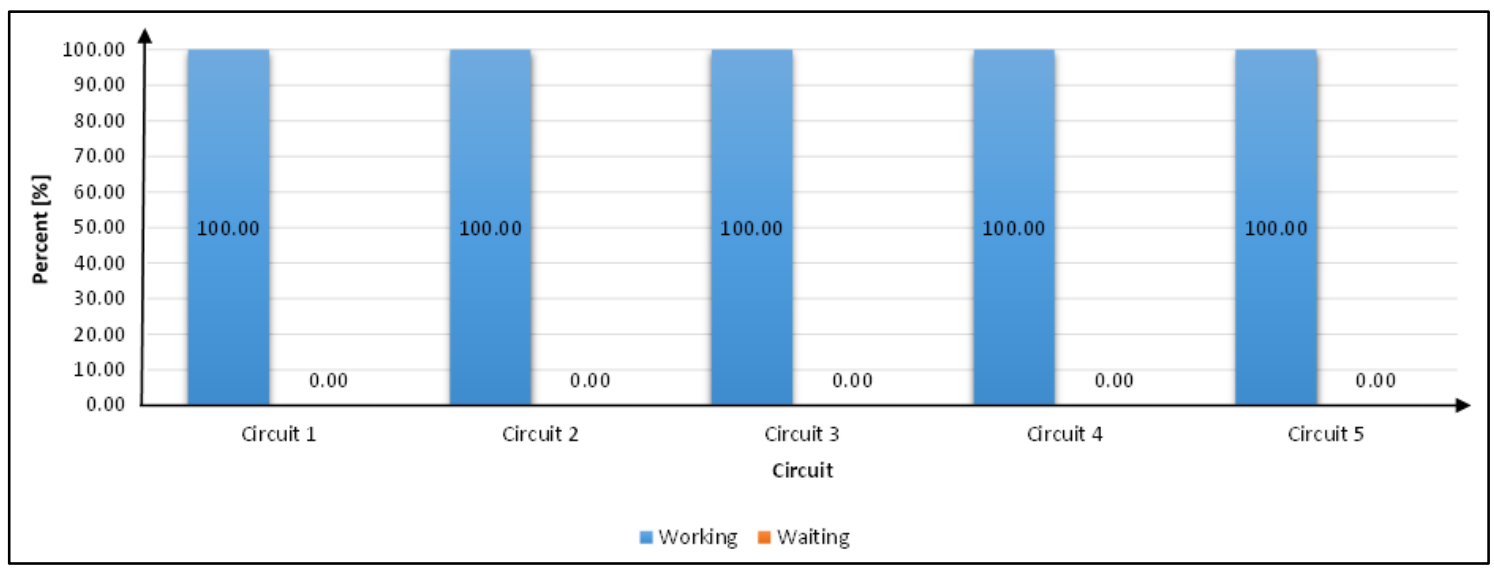

Figure 10: Impact of supply on the activity of production facilities - Variant "C".

\subsection{Summary and evaluation of proposals}

Based on the analysis and experimentation in the simulation model, we can conclude that due to the issue of capacity increase in a given section, it is necessary to modify a single route from the five circuits examined. In this case, it is the addition of 4 part of the AGV technique, which, however, causes the current infrastructure to be blocked on the basis of simulation outputs. For this reason, when designing as an ideal variant "C", it is also necessary to rebuild one route, the Circuit 5 route. At the same time, with this redevelopment, we are gaining the possibility of further expanding production and supply capacities. A brief summary of each proposal's facts (see Table IV).

Table IV: Summary of the facts for each proposal.

\begin{tabular}{|c|c|c|c|}
\hline Variant & Plus & Minus & Recommendation \\
\hline \multirow[t]{2}{*}{ A } & $\begin{array}{l}\text { without change of } \\
\text { infrastructure }\end{array}$ & \multirow{2}{*}{$\begin{array}{l}\text { the simulation output shows high } \\
\text { risk of production delays }\end{array}$} & \multirow[t]{2}{*}{ not realised } \\
\hline & simple and fast deployment & & \\
\hline \multirow{2}{*}{ B } & $\mathrm{C}_{2}$ & $\begin{array}{l}\text { high costs (forced change of } \\
\text { parallel processes) }\end{array}$ & \multirow{2}{*}{ not realised } \\
\hline & - & $\begin{array}{l}\text { high time requirement (change } \\
\text { parallel processes) }\end{array}$ & \\
\hline \multirow{2}{*}{$\mathrm{C}$} & $\begin{array}{l}\text { the simulation output } \\
\text { confirmed the feasibility }\end{array}$ & $\begin{array}{l}\text { higher time-consuming towards } \\
\text { "A" (rebuilding) }\end{array}$ & \multirow{2}{*}{$\begin{array}{l}\text { suitable for } \\
\text { application }\end{array}$} \\
\hline & $\begin{array}{c}\text { possibility of another } \\
\text { potential capacity expansions }\end{array}$ & $\begin{array}{l}\text { slightly higher investments towards } \\
\text { "A" }\end{array}$ & \\
\hline
\end{tabular}

Based on the facts established and the experiments carried out on simulation models, a "C" proposal is recommended. A feasible solution without risking compromising production processes.

Economic assessment of the recommended proposal: In the previous section, based on the finding and recommendation simulation, the proposal " $\mathrm{C}$ " was found as a technically feasible and effective solution. To recommend a solution, the following section quantifies the costs associated with these changes. In the cost analysis, it was found that the financial difference in the investments needed to carry out proposal "A" and proposal "B" was not significant in relation to the total investment. 
The costs can be divided into three types, i.e. adjustment of routes, AGV tractors and trucks to the set. This division shows that investment in tractors, trucks, and integration must be paid for in each of the proposals (other technology from static conversion). The difference is, therefore, only the modification of the route. The amount of investment is around 10,000 $€$. After the overall calculation of the ROI - the return of investment, in this case, is 1.69 years. This means that if we had made the adjustment conventionally and had direct personnel costs, rental of conventional equipment, etc., we would have incurred the costs in as early as 1.69 years. During the further running of the process, we would only lose or use resources beyond the investment's total value.

\section{DISCUSSION}

The study's main finding consists of simulation verification, the accuracy of the results of simulation experiments, current state and variants for conducting experiments.

Simulation verification of the proposed solution helps to detect shortcomings before it is put into production: This conclusion can be reached in sub-chapter 3.2 where a series of experiments has been carried out after the simulation model has been developed. The first variants $\mathrm{A}$ and $\mathrm{B}$ were at the beginning proposed as the preferred solution. However, the negative effects of these variants on the supply system were discovered during the experiments. The main route of all five circuits was primarily blocked in experiment A, due to the circuits' undersizing. Option B found that no expansion of waiting positions is feasible based on the current layout of the hall and the layout of other processes in this segment.

The accuracy of the simulation experiments results depends on the simulation model's validity: The simulation model is sensitive to the degree of abstraction of the elements of the real system. If there were too much abstraction, then the simulation results would not realistically respond to the real system's course. With appropriate abstraction created by us, the model showed a low need for computing power. The submitted model was validated and validated according to the real system and showed high compliance.

When planning optimisations of supply processes, it is necessary to consider the current state: The assigning of dimensions to objects and entities according to the real state of production is an essential part of modelling processes that depend on lengths. In our case, it was the assigning of measurements and numbers to the trucks that are pulled behind the AGV. Also crucial in modelling is the correct allocation of planes and arcs' transport lengths and the speeds that real AGV achieves in production before and after unloading in these locations. In transport processes, the logic of activities is important, which has been processed using different methods.

When creating variants for conducting experiments, it is advisable to take into account the results of previous experiments: Part of the selection of the named parameters that are defined in the description of the variant is the recording of results from the previous simulation runs. Each parameter in the variant is reflected in the result of the experiment. Therefore, it is appropriate to isolate those that positively affect the system and to include them in other experiments. This was also the case in our case when experiment $\mathrm{C}$ was created by selecting the most appropriate parameters from the first two variants $\mathrm{A}$ and $\mathrm{B}$ and adding a change in the parameters that were not used.

\section{CONCLUSIONS}

The article in question is dedicated to constructing a simulation model, which is a virtual image of the real logistics system and experimentation with this model. A model is presented to demonstrate the potential of modelling and simulation in logistics optimization. Simulation is 
a good way to easily determine the existing status of a plant layout and future improvements. The work's advantages included verifying, choosing a technological solution by simulation, and estimating the amount of costs for process innovation. The proposals made following the request to address the increase in production and supply capacities were examined in simulation experiments, which helped detect and confirm an appropriate solution to the problem.

From three proposed solutions, one was chosen for implementation as the best. Simultaneously, the financial analysis confirmed that the economy of the proposed solution investment of about $10,000 €$ is returned in 1.69 years. A dynamic simulation is a tool that can not only detect bottlenecks and provide space to respond by early intervention in planning but helps to find suitable solutions by eliminating unwanted effects such as forced multiple - costs associated with possible wrong decision or purchase of unnecessary technology that will not be used or has low usability. Thus, unnecessary investments will not be negatively reflected in the overall price of the product. In the future, such verification will be gradually applied to all production lines in the context of the factory of the future.

\section{ACKNOWLEDGEMENTS}

This work was supported by the KEGA Agency under the Contract no. KEGA 020ŽU-4/2019.

\section{REFERENCES}

[1] Micieta, B.; Dulina, L.; Malcho, M. (2005). Main factors of the selection jobs for the work study, Proceedings of the $16^{\text {th }}$ International DAAAM Symposium, 249-250

[2] Bubeník, P.; Horák, F. (2014). Proactive approach to manufacturing planning, Quality Innovation Prosperity, Vol. 18, No. 1, 23-32, doi:10.12776/qip.v18i1.208

[3] Dulina, L.; Malcho, M.; Micieta, B. (2003). Optimal utilisation of the employees potention in the manufacturing condition, Proceedings of the $14^{\text {th }}$ International DAAAM Symposium, 129-130

[4] Micieta, B.; Fusko, M.; Binasova, V.; Furmannova, B. (2020). Business model canvas in global enterprises, Proceedings of the $19^{\text {th }}$ International Scientific Conference Globalisation and its SocioEconomic Conseqences, Vol. 74, Paper 02010, 7 pages, doi:10.1051/shsconf/20207402010

[5] Votava, V.; Ulrych, Z.; Edl, M.; Korecký, M.; Trkovský, V. (2008). Analysis and optimisation of complex small-lot production in new manufacturing facilities based on discrete simulation, Proceedings of $20^{\text {th }}$ European Modeling \& Simulation Symposium (EMSS 2008), 198-203

[6] Law, A. M. (2015). Simulation Modeling and Analysis, $5^{\text {th }}$ edition, McGraw-Hill, New York

[7] Sobrino, D. R. D.; Koštál, P.; Cagáňová, D.; Čambál, M. (2013). On the possibilities of intelligence implementation in manufacturing: the role of simulation, Applied Mechanics and Materials, Vol. 309, 96-104, doi:10.4028/www.scientific.net/AMM.309.96

[8] Gola, A. (2019). Reliability analysis of reconfigurable manufacturing system structures using computer simulation methods, Eksploatacja i Niezawodnosc - Maintenance and Reliability, Vol. 21, No. 1, 90-102, doi:10.17531/ein.2019.1.11

[9] Gola, A.; Klosowski, G. (2019). Development of computer-controlled material handling model by means of fuzzy logic and genetic algorithms, Neurocomputing, Vol. 338, 381-392, doi:10.1016/ j.neucom.2018.05.125

[10] Schickerle, M. (2017). Využitie počitačovej simulácie pri zefektivneni vybraného procesu (Use of computer simulation to streamline the selected process), Diploma thesis, University of Žilina, Žilina, 67 pages (in Slovak)

[11] Bocewicz, G.; Nielsen, I.; Gola, A.; Banaszak, Z. (2020). Reference model of milk-run traffic systems prototyping, International Journal of Production Research, Vol. 59, No. 15, 4495-4512, doi: $10.1080 / 00207543.2020 .1766717$

[12] Mikusova, M.; Callejas-Cuervo, M.; Valero-Bustos, H. A.; Alarcon-Aldana, A. C. (2019). Integration of simulation techniques: system dynamics and intelligent agents applied to a case study, Nguyen, N.; Chbeir, R.; Exposito, E.; Aniorté, P.; Trawiński, B. (Eds.), Computational Collective Intelligence (ICCCI 2019), Springer, Cham, 510-517, doi:10.1007/978-3-030-28374$\underline{244}$ 
[13] Gracanin, D.; Lalic, B.; Beker, I.; Lalic, D.; Buchmeister, B. (2013). Cost-time profile simulation for job shop scheduling decisions, International Journal of Simulation Modelling, Vol. 12, No. 4, 213-224, doi:10.2507/IJSIMM12(4)1.237

[14] Bučkova, M.; Krajčovič, M.; Plinta, D. (2019). Use of dynamic simulation in warehouse designing, Burduk, A.; Chlebus, E.; Nowakowski, T.; Tubis, A. (Eds.), Intelligent Systems in Production Engineering and Maintenance (ISPEM 2018), Springer, Cham, 485-498, doi:10.1007/978-3-31997490-3 47

[15] Mikusova, M.; Abdunazarov, J.; Zukowska, J.; Jagelcak, J. (2020). Designing of parking spaces on parking taking into account the parameters of design vehicles, Computation, Vol. 8, No. 3, Paper 71, 21 pages, doi:10.3390/computation8030071

[16] Bubenik, P. (2004). A scheduling system for minimising the costs of production, Strojniski vestnik - Journal of Mechanical Engineering, Vol. 50, No. 5, 291-297

[17] Trebuna, P.; Pekarcikova, M.; Edl, M. (2019). Digital value stream mapping using the Tecnomatix Plant Simulation software, International Journal of Simulation Modelling, Vol. 18, No. 1, 19-32, doi:10.2507/IJSIMM18(1)455

[18] Worobel, R.; Capek, J.; Kovacova, L.; Bubenik, P.; Krajcovic, M. (2018). Improving business processes using simulation tools, MM Science Journal, Vol. 2018, March issue, 2244-2251, doi:10.17973/MMSJ.2018 $03 \quad 2017103$

[19] Bertoncel, T.; Meško, M.; Bach, M. P. (2019). Big data for smart factories: a bibliometric analysis, Proceedings of the $201942^{\text {nd }}$ International Convention on Information and Communication Technology, Electronics and Microelectronics, 1261-1265, doi:10.23919/MIPRO.2019.8756962

[20] Bučková, M.; Skokan, R.; Fusko, M.; Hodoň, R. (2019). Designing of logistics systems with using of computer simulation and emulation, Transportation Research Procedia, Vol. 40, 978-985, doi:10.1016/j.trpro.2019.07.137

[21] Furmann, R.; Furmannova, B.; Wiecek, D. (2017). Interactive design of reconfigurable logistics systems, Procedia Engineering, Vol. 192, 207-212, doi:10.1016/j.proeng.2017.06.036 